\title{
A Rewarding Year: The Congressional Fellowship Experience
}

\author{
David L. Leal, University at Buffalo, SUNY
}

The goal of APSA's Congressional Fellowship Program is simple: to help participants better understand Congress. Few scholars claim that the institution is transparent, especially when there are contentious debates in the literature about deceptively simple propositions. While we can learn much in a university setting, there is much to be gained by experiencing Congress from the inside. In this short essay I will outline the value of the Congressional Fellowship, especially how it can help fellows meet many professional and personal goals, and why it was worth a year of my life.

The greatest professional benefit of the fellowship is that it promotes good congressional research. Some fellows arrive in Washington with a research agenda and find jobs that help them carry it out. Others have no specific plans but find that the atmosphere generates ideas. The year allows fellows to gain the experience to identify important questions that the discipline may not be asking, find new and creative ways to solve existing puzzles, and rigorously test the conventional wisdom.

The APSA library is filled with books and articles written as a consequence of the fellowship. Methodological approach does not matter; statisticians, interviewers, and modelers are all motivated to find and answer interesting questions, and the fellowship is a great facilitator of both. As such, it is a valuable means to finding a "second project" after the dissertation (or even a third or a fourth).

It is also a great way to make professional and political contacts. The fellowship attracts all kinds of congressional scholars, as well as people who primarily study elections or policy areas. Fellows often find new coauthors among this group, and at the very least end the year with more friends to see at the next academic conference. The weekly seminars also introduce fellows to senior congressional staffers and scholars, who cover most aspects of Congress, ranging from staffing to media coverage. Other events feature wellknown political personalities, such as politicians, think-tank scholars, and journalists.

I particularly learned a great deal about how legislation is made. I figured, "Why read about the legislative sausage maker when I could turn the handle myself?" What exactly did I do? I wrote legislative language, advised my boss on votes big and small, researched the issues of the moment, put a lot of money into soft drink machines, kept track of legislation on the floor, worked with staffers from other offices, watched Senators negotiate in the cloakrooms, worked until midnight during stacked votes, talked with issue groups, put a lot of money into junk food machines, met with constituents, read the Hotline every day, and wore a bow tie that made Sam Blowback smile. Short of becoming a member of Congress myself, a la David Price (D-NC), this was the best possible way to experience the institution.

Keep in mind that all of the above was fun. Sure, the work was hard, but I often had that "I can't believe I get paid for this" feeling. Some days were like riding into town with Clint Eastwood and challenging the bad guys. On other days, the history of the place loomed large and I felt honored to work in a building where Kennedy, Johnson, Truman, and so many others once walked the halls. My class was even able to experience history, as we ere on the Hill during impeachment.

The fellowship also provides time to think about career issues. I often met people who had no idea what political science is like. They asked me what I studied, how I did it, and whether anything I knew applied to the job at hand. This challenged me in a way normal political science life never did. It also introduced me to a career path very different from academia. It is not uncommon for fellows to decide that real politics is much more exciting. Even if the ex- perience confirms fellows' choice of the academy, they at least have a much clearer sense of the benefits and costs of each career.

The experience certainly helps fellows' teaching and, perhaps, their student evaluations. The more cynical fellows may think this will not factor into their future. I am not so sure. More universities are considering posttenure review and weighing teaching evaluations more heavily in promotion decisions. Professors who understand the people, issues, and processes of everyday politics and can explain them well may become more prized than those who can only refer to textbook descriptions.

Serving a fellowship may even renew one's faith in democracy. Cynicism is everywhere today. We hear it from students, relatives, TV commentators, and polls. Working in Congress shows that democracy not only lives but prospers. It may be messy, one's side may sometimes (or often) lose, but we have a political system in which ideas matter and the public is usually heard. I was impressed by the dedication and competence of most of the staff, the seriousness of most members, and I grew to better appreciate our democratic keystone.

It is sometimes said that American politics is an area study, and the only one that does not require fieldwork. The APSA Congressional Fellowship Program provides a unique and exciting chance to get out in the field and immerse one's self in a key democratic institution. It enables fellows to conduct better research and teach better classes and also provides them an unforgettable personal experience.

David L. Leal was the William Steiger Fellow for 1998-99. He worked for Sen. John F. Kerry (D-MA). His thanks go to Jeffrey Biggs and Eric Heberlig for their comments on this essay. To learn more about the program, visit the CFP web site (www.apsanet.org/about/cfp/). 